\title{
Isocratic High Performance Liquid Chromatography Assay for Quantification of Ceftiofur Hydrochloride in Bubaline Plasma
}

\section{Muhammad Adil,, ${ }^{1,2}$ Muhammad Ovais Omer, ${ }^{2, *}$ Aqeel Javeed, ${ }^{2}$ Aamir Ghafoor, ${ }^{3}$ Muhammad Ashraf ${ }^{2}$ and Abdul Muqeet Khan ${ }^{4}$}

${ }^{1}$ Pharmacology and Toxicology Section, University of Veterinary and Animal Sciences (UVAS), Lahore-Jhang Campus, Pakistan.

\author{
${ }^{2}$ Department of Pharmacology and Toxicology, University of Veterinary and Animal Sciences (UVAS), Lahore, Pakistan. \\ ${ }^{3}$ University Diagnostic Laboratory (UDL), University of Veterinary and Animal Sciences (UVAS), Lahore, Pakistan. \\ ${ }^{4}$ Quality Operations Laboratory (QOL), University of Veterinary and Animal Sciences (UVAS), Lahore, Pakistan. \\ *Corresponding author: E-mail: drovaisomer@uvas.edu.pk \\ Contact no. +923334244780
}

Received: 01-03-2019

\begin{abstract}
We optimized and validated an isocratic high-performance liquid chromatography (HPLC) assay for quantification of ceftiofur hydrochloride in bubaline plasma. Ceftiofur, its metabolic products and protein-bound residues were cleaved, derivatized into desfuroylceftiofur acetamide and injected into HPLC system. The mobile phase comprising of sodium dihydrogen phosphate $(0.025 \mathrm{M}, \mathrm{pH} 7)$ and acetonitrile $(34: 66, \mathrm{v} / \mathrm{v})$, was driven at a flow rate of $1 \mathrm{~mL} / \mathrm{min}$, and separation was achieved using C18 column. Isocratic elution was performed with an injection volume of $45 \mu \mathrm{L}$ and analyte was scanned at $310 \mathrm{~nm}$. The linearity range, limit of detection and limit of quantification were $0.1-10 \mu \mathrm{g} / \mathrm{mL}, 0.03 \mu \mathrm{g} / \mathrm{mL}$ and $0.11 \mu \mathrm{g} / \mathrm{mL}$ respectively. Moreover, the accuracy, precision and recovery remained within the acceptable limits. The assay was effectively applied for determining the concentration of ceftiofur in plasma samples collected from ceftiofur-treated buffalo calves.
\end{abstract}

Keywords: Ceftiofur hydrochloride; bubaline plasma; isocratic; HPLC

\section{Introduction}

Ceftiofur represents a broad-spectrum, bactericidal, third generation cephalosporin antibiotic specifically developed for use in veterinary medicine. ${ }^{1}$ It is available as ceftiofur hydrochloride, ceftiofur sodium and ceftiofur crystalline-free acid suspension. The chemical formula of ceftiofur hydrochloride is $\mathrm{C}_{19} \mathrm{H}_{17} \mathrm{~N}_{5} \mathrm{O}_{7} \mathrm{~S}_{3} \cdot \mathrm{HCl}$ with a molecular weight of 560.2 grams. The chemical structure of ceftiofur hydrochloride has been illustrated in Figure $1 .^{2}$ Many gram-positive, gram negative and anaerobic bacterial pathogens of domestic animals are susceptible to ceftiofur. ${ }^{3}$ The ready-to-use, parenteral formulation of ceftiofur hydrochloride is predominantly used against the bacterial respiratory disease affecting cattle and pigs. ${ }^{4}$ Additionally, it is also approved for the treatment of acute foot rot and postpartum metritis in cattle. ${ }^{5}$ Desfuroylceftiofur consti- tutes the primary metabolite of ceftiofur with proven antimicrobial activity. ${ }^{6}$ The most primitive analytical assay for estimation of ceftiofur in biological fluids involved the derivatization of parent drug and resultant metabolites followed by a time-consuming, solid-phase extraction process. ${ }^{7,8}$ Furthermore, the suggested alternative method was only applicable for quantification of parent drug without determining the concentration of microbiologically active metabolic compounds. ${ }^{9}$ Subsequent modification of the conventional analytical method led to simplified assays involving the direct HPLC injection of derivatized sample without solid-phase extraction clean-up. ${ }^{10,11}$ Nevertheless, there is scarcity of literature regarding the isocratic, HPLCbased analysis of ceftiofur in water buffalo plasma. Consequently, an isocratic, HPLC assay was optimized and validated for the quantitative assessment of ceftiofur hydrochloride in bubaline plasma. 


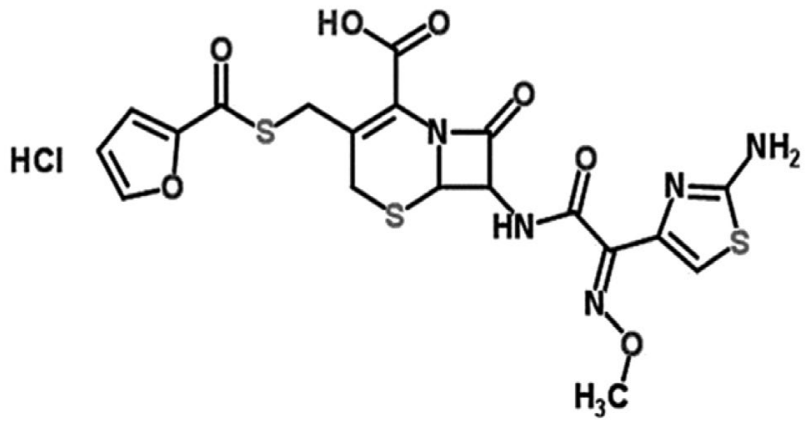

Figure 1. Chemical structure of ceftiofur hydrochloride (modified from Palur et al.2)

\section{Experimental}

\section{1. Reference Standard and Chemicals}

The analytical reference standard and injectable formulation of ceftiofur hydrochloride were generously provided by M/S International Pharma Labs, Lahore, Pakistan and M/S Nawan Laboratories (PVT) LTD., Karachi, Pakistan respectively. Dithioerythritol and iodoacetamide were supplied by Sigma-Aldrich (St. Louis, MO, USA). Acetonitrile, disodium tetraborate, sodium dihydrogen phosphate and sodium phosphate dibasic heptahydrate were procured from Merck Millipore, Germany.

\section{2. Preparation of Standard Solutions, Buffers and Reagents}

The stock solution of ceftiofur hydrochloride $(1 \mathrm{mg} /$ $\mathrm{mL}$ ) was prepared in distilled water and diluted further to obtain the quality control (QC) samples and calibration standards. The QC samples of low, medium and high concentrations were prepared in distilled water at concentrations of $0.75,2.5$ and $12.5 \mu \mathrm{g} / \mathrm{mL}$ respectively. Whereas, the calibration standards of ceftiofur hydrochloride were prepared at concentrations of $0.1,0.15,0.2,0.25,0.5,1,5$ and $10 \mu \mathrm{g} / \mathrm{mL}$ in buffalo plasma. Borate buffer $(0.05 \mathrm{M}, \mathrm{pH}$ 7) was prepared by dissolving 1.9 grams of disodium tetraborate in $100 \mathrm{~mL}$ of distilled water. Moreover, 0.14 grams of sodium dihydrogen phosphate and 0.38 grams of sodium phosphate dibasic heptahydrate were dissolved in 100 $\mathrm{mL}$ of distilled water for the preparation of phosphate buffer $(0.025 \mathrm{M}, \mathrm{pH} 7)$. The working solutions of iodoacetamide $(0.54 \mathrm{M})$ and dithioerythritol $(0.66 \mathrm{M})$ were obtained by separately dissolving 1 gram each of iodoacetamide and dithioerythritol in $10 \mathrm{~mL}$ of phosphate buffer and borate buffer respectively.

\subsection{Synthesis and Derivatization of Desfuroylceftiofur}

All plasma samples, calibration standards and QC samples were processed for the synthesis of desfuroylceft- iofur and subsequent derivatization into desfuroylceftiofur acetamide. In brief, each sample was transferred into a $2 \mathrm{~mL}$ microcentrifuge tube and $200 \mu \mathrm{L}$ of methanol was added. The samples were vortexed for 30 seconds and centrifuged at $13000 \mathrm{rpm}$ for $10 \mathrm{~min}$. The supernatants were collected in separate $2 \mathrm{~mL}$ microcentrifuge tubes, mixed with $100 \mu \mathrm{L}$ of dithioerythritol solution $(0.66 \mathrm{M})$ and kept in water bath at $50{ }^{\circ} \mathrm{C}$ for $15 \mathrm{~min}$. Subsequently the tubes were allowed to attain room temperature and covered with aluminum foil after adding $100 \mu \mathrm{L}$ of iodoacetamide solution $(0.54 \mathrm{M})$. The contents of each tube were centrifuged at $350 \mathrm{rpm}$ for $45 \mathrm{~min}$ and mixed with $25 \mu \mathrm{L}$ of formic acid. Stirring was carried out at $22^{\circ} \mathrm{C}$ and the tubes were placed in vortex mixer for 30 seconds. Final centrifugation was performed at $13000 \mathrm{rpm}$ for $10 \mathrm{~min}$ and $45 \mu \mathrm{L}$ of each supernatant was injected into the HPLC system.

\section{4. HPLC System and Chromatographic Conditions}

The HPLC system comprised of an auto-sampler (SIL-10AC), system control module (CBM-20A), pump (Schimadzu LC-20AT), column oven (CTO-20AC), degasser (DGU-20A), ultraviolet-visible (UV-VIS) detector (SPD-M20A) and low pressure-gradient flow control valve (FCV-10AL). The chromatograms of QC and calibration samples obtained through C18 and PLRP-S columns were compared for the selection of appropriate analytical column. Several types of mobile phase having varying combinations of $0.1 \%$ trifluoroacetic acid and sodium dihydrogen phosphate $(0.025 \mathrm{M}, \mathrm{pH} 7)$ with acetonitrile were tested after filtration through $0.45 \mu \mathrm{m}$ nylon filter (Sartorius, Gottingen, Germany) and sonication for $30 \mathrm{~min}$. Assessment of various flow rates $(0.5-1.5 \mathrm{~mL} / \mathrm{min})$ and wave lengths $(254,265,266$ and $310 \mathrm{~nm})$ was also performed. Isocratic elution was carried out with an injection volume of $45 \mu \mathrm{L}$ and the column oven was set at $37^{\circ} \mathrm{C}$. Liquid Chromatography (LC) Solutions' software (SSI, Kyoto, Japan) was employed for instrument control and analysis of data.

\section{5. Validation of HPLC Method}

The proposed assay was validated for linearity, sensitivity, precision, accuracy, recovery and freeze-thaw stability, in compliance with the recommendations of International Conference on Harmonization (ICH). ${ }^{12}$

\section{6. Linearity}

The representative concentrations of ceftiofur $(0.1$ to $10 \mu \mathrm{g} / \mathrm{mL}$ ) were plotted against corresponding peak areas and resultant calibration curve was used to evaluate the linearity of HPLC method. ${ }^{13}$ The correlation co-efficient, slope and intercept of standard curve were calculated. 


\subsection{Sensitivity}

The sensitivity of HPLC method was established as the limit of detection (LOD) and limit of quantification (LOQ). The standard deviation of $y$-intercept of regression line and slope of calibration curve were used to calculate the LOD and LOQ by means of equations 1 and 2 respectively. ${ }^{14}$

$$
\begin{aligned}
& \mathrm{LOD}=3.3(\sigma / \mathrm{S}) \\
& \mathrm{LOQ}=10(\sigma / \mathrm{S})
\end{aligned}
$$

where " $\sigma$ " represents the standard deviation of y-intercept of regression line and " $\mathrm{S}$ " denotes the slope of regression line.

\section{8. Accuracy and Precision}

The intra-day and interday precision, and accuracy were estimated in terms of percent relative standard deviation (RSD \%) and percent bias (bias \%) respectively. ${ }^{15}$

\section{9. Absolute Recovery (Extraction Efficiency)}

Peak areas of extracted ceftiofur-containing plasma samples and un-extracted samples of equal concentrations prepared in mobile phase were compared for the calculation of absolute recovery. ${ }^{16}$

\section{10. Freeze-Thaw Stability}

Six replicates of each low and high QC samples were analyzed over two freeze-thaw cycles within three days for freeze-thaw stability assessment. The samples frozen at $-20{ }^{\circ} \mathrm{C}$ for $24 \mathrm{~h}$ were subjected to unassisted thawing at room temperature. Three replicates of each QC sample were evaluated, while the remaining samples underwent refreezing at $-20{ }^{\circ} \mathrm{C}$ for $24 \mathrm{~h}$. Freeze-thaw stability was estimated by comparing the relative concentrations of freshly prepared samples and QC samples following the $1^{\text {st }}$ and $2^{\text {nd }}$ freeze-thaw cycles. ${ }^{17}$

\section{11. Application of Assay for Quantification of Ceftiofur Hydrochloride in Buffalo Plasma}

The analytical method was applied for estimation of ceftiofur in plasma samples, collected at $10 \mathrm{~min}$ after the intramuscular and subcutaneous administration of ceftiofur hydrochloride (Cefur ${ }^{\circledR}$ RTU injection; Nawan Laboratories (PVT) LTD., Karachi, Pakistan) in buffalo calves following a dose rate of $2.2 \mathrm{mg} / \mathrm{Kg}$ body weight. ${ }^{18}$ The procedures for care and handling of experimental animals were approved by the Institutional Ethical Committee,
University of Veterinary and Animal Sciences, Lahore, Pakistan (Letter No. DR/214, dated 30-03-2017).

\section{Results and Discussion}

\section{1. Derivatization and Extraction of Desfuroylceftiofur}

Desfuroylceftiofur was cleaved and stabilized to yield desfuroylceftiofur acetamide by mixing $0.2 \mathrm{~mL}$ of each sample with $0.1 \mathrm{~mL}$ each of dithioerythritol and iodoacetamide respectively. Hence, the cleavage and derivatization were carried out following the previously documented procedure ${ }^{10,11}$ with slight modification. Moreover, the final clean-up was successfully accomplished without solid-phase extraction, as described by earlier studies. ${ }^{10,11}$ Whereas, typical analytical assays suggested either single, double or triple steps of solid-phase extraction for final clean-up. ${ }^{7,8,19}$

\section{2. Chromatographic Conditions}

The $\mu$-Bondapack C18 column $(250 \mathrm{~mm} \times 4.6 \mathrm{~mm}$; internal diameter, $5 \mu \mathrm{m}$; Supelco, Bellefonte, PA, USA) was chosen for analytical assay on the basis of retention time and peak symmetry. Beckoni-Barkar et al. ${ }^{19}$ and Jacobson et al. ${ }^{10}$ also employed C18 column, whereas, De Baere et al. ${ }^{8}$ and Altan et al. ${ }^{11}$ used PLRP-S column. In current study, the combination of sodium dihydrogen phosphate $(0.025 \mathrm{M}, \mathrm{pH} 7)$ and acetonitrile $(34: 66, \mathrm{v} / \mathrm{v})$ provided most suitable results, while, earlier studies primarily used the mobile phase consisting of $0.1 \%$ trifluoroacetic acid and acetonitrile or water. ${ }^{8,10,19}$ Under the prescribed HPLC conditions of isocratic elution, the retention time was 6.8 min with a total run time of $10 \mathrm{~min}$. In contrast, virtually all the previous methods were based on gradient elution, characterized by relatively longer retention times. ${ }^{7,10,11,19}$ The selected flow rate of $1 \mathrm{~mL} / \mathrm{min}$ provided optimum resolution thus reinforcing the findings of earlier studies. ${ }^{7,10,19}$ Whereas, De Baere et al. ${ }^{8}$ and Altan et al. ${ }^{11}$ reported comparatively lower flow rates of $0.4 \mathrm{~mL} / \mathrm{min}$ and $0.3 \mathrm{~mL} / \mathrm{min}$ respectively. The UV-VIS detector and column oven were set at $310 \mathrm{~nm}$ and $37^{\circ} \mathrm{C}$ respectively. Conversely, relatively shorter wave lengths i.e., $254 \mathrm{~nm}^{7}, 265 \mathrm{~nm}^{10}$ and $266 \mathrm{~nm}^{8,11,19}$ were previously used for peak detection.

\section{3. Validation of HPLC Assay}

The calibration curve of ceftiofur was linear over the range of 0.1 to $10 \mu \mathrm{g} / \mathrm{mL}$ with $\mathrm{r}^{2}=0.999$ (Table 1). The LOD and LOQ of current analytical method were $0.03 \mu \mathrm{g} /$ $\mathrm{mL}$ and $0.11 \mu \mathrm{g} / \mathrm{mL}$ respectively. Former studies have reported either comparable ${ }^{11,19}$ or relatively lower ${ }^{8,10}$ sensitivities. 
Table 1. Linearity data of analytical assay

\begin{tabular}{ll}
\hline Regression parameter & Value \\
\hline $\mathrm{r}^{2}$ & 0.999 \\
Slope & 55886 \\
Intercept & 6245.2 \\
Concentration range & $0.1-10 \mu \mathrm{g} / \mathrm{mL}$ \\
\hline
\end{tabular}

Table 2 indicates the estimated accuracy and precision of HPLC assay. The within-day and between-day accuracy ranged from -0.08 to $-4.00 \%$ and -0.24 to $-1.33 \%$ respectively. The precision levels of proposed assay were 0.08 to $4.05 \%$ and 0.16 to $1.35 \%$ on intra-day and interday basis respectively. In all conditions, the accuracy and precision remained within the acceptable ranges of $\pm 15 \%$ and

Table 2. Within-day and between-day accuracy and precision of analytical assay

\begin{tabular}{|c|c|c|c|c|c|}
\hline \multirow{2}{*}{$\begin{array}{l}\text { Spiked } \\
\text { concentration } \\
(\mu \mathrm{g} / \mathrm{mL})\end{array}$} & \multirow[t]{2}{*}{ Parameter } & \multicolumn{3}{|c|}{ Within-day $(n=6)$} & \multirow{2}{*}{$\begin{array}{c}\text { Between-day } \\
\quad(n=18)\end{array}$} \\
\hline & & Day 1 & Day 2 & Day 3 & \\
\hline & $\begin{array}{l}\text { Mean nominal concentration } \\
(\mu \mathrm{g} / \mathrm{mL})\end{array}$ & & & & \\
\hline 0.75 & & 0.74 & 0.72 & 0.73 & 0.74 \\
\hline 2.5 & & 2.46 & 2.48 & 2.49 & 2.48 \\
\hline \multirow[t]{2}{*}{12.5} & & 12.48 & 12.46 & 12.49 & 12.47 \\
\hline & Standard deviation & & & & \\
\hline 0.75 & & 0.03 & 0.02 & 0.02 & 0.01 \\
\hline 2.5 & & 0.02 & 0.02 & 0.01 & 0.01 \\
\hline \multirow[t]{2}{*}{12.5} & & 0.01 & 0.03 & 0.01 & 0.02 \\
\hline & Accuracy (\% Bias) & & & & \\
\hline 0.75 & & -1.33 & -4.00 & -2.66 & -1.33 \\
\hline 2.5 & & -1.60 & -0.80 & -0.40 & -0.80 \\
\hline \multirow[t]{2}{*}{12.5} & & -0.16 & -0.32 & -0.08 & -0.24 \\
\hline & Precision $\left({ }^{\star *}\right.$ RSD \%) & & & & \\
\hline 0.75 & & 4.05 & 2.77 & 2.73 & 1.35 \\
\hline 2.5 & & 0.81 & 0.80 & 0.40 & 0.40 \\
\hline 12.5 & & 0.08 & 0.24 & 0.08 & 0.16 \\
\hline
\end{tabular}

Table 3. Absolute recovery of HPLC method

\begin{tabular}{lcccc}
\hline $\begin{array}{l}\text { Spiked } \\
\text { concentration } \\
(\boldsymbol{\mu g} / \mathbf{m L})\end{array}$ & $\begin{array}{c}\text { Mean peak area } \\
\text { of plasma samples } \\
\text { after extraction }\end{array}$ & $\begin{array}{c}\text { Mean peak area } \\
\text { of QC samples } \\
\text { without extraction }\end{array}$ & \% Recovery & $\begin{array}{c}\text { Standard } \\
\text { deviation }\end{array}$ \\
\hline 0.75 & 49018 & 53397 & 92.1 & 0.25 \\
2.5 & 147221 & 157237 & 93.2 & 0.29 \\
12.5 & 696076 & 731958 & 94.9 & 0.28 \\
\hline
\end{tabular}

Table 4. Freeze-thaw stability of quality control samples

\begin{tabular}{|c|c|c|c|c|c|}
\hline \multirow[t]{2}{*}{ Storage condition } & \multirow[t]{2}{*}{ Quality control level } & \multirow[b]{2}{*}{$\begin{array}{l}\text { Spiked concentration } \\
\qquad(\mu \mathrm{g} / \mathrm{mL})\end{array}$} & \multicolumn{2}{|c|}{ Parameters } & \multirow[b]{2}{*}{ \% Stability } \\
\hline & & & $\begin{array}{c}\text { Mean nominal } \\
\text { concentration }(\mu \mathrm{g} / \mathrm{mL})\end{array}$ & $\begin{array}{l}\text { Standard } \\
\text { deviation }\end{array}$ & \\
\hline \multicolumn{6}{|l|}{ Fresh samples } \\
\hline & Low concentration & 0.75 & 0.75 & 0.003 & 100 \\
\hline & High concentration & 12.5 & 12.5 & 0.126 & 100 \\
\hline \multicolumn{6}{|l|}{ Freeze thaw cycle 1} \\
\hline & Low concentration & 0.75 & 0.73 & 0.012 & 97.3 \\
\hline & High concentration & 12.5 & 12.25 & 0.130 & 98.0 \\
\hline \multicolumn{6}{|l|}{ Freeze thaw cycle 2} \\
\hline & Low concentration & 0.75 & 0.71 & 0.016 & 94.6 \\
\hline & High concentration & 12.5 & 11.92 & 0.096 & 95.3 \\
\hline
\end{tabular}


$<15 \%$ respectively. ${ }^{20}$ These values are in agreement with the findings of Jacobson et al. ${ }^{10}$

The values of extraction recovery were calculated as 92.1\%, 93.2\% and 94.9\% for low, medium and high QC samples respectively (Table 3 ). Hence the recovery of analyte was rather equivalent to that documented by Jacobson et al. ${ }^{10}$ but higher than the findings of Jaglan et al. ${ }^{7}$ and De Baere et al. ${ }^{8}$

Furthermore, the proposed assay exhibited efficient quantification of ceftiofur in QC samples exposed to freeze-thaw cycles. The stability of low QC samples following the $1^{\text {st }}$ and $2^{\text {nd }}$ post-thaw cycles were estimated as 97.3\% and 94.6\% respectively. Likewise, the high QC samples remained $98 \%$ and $95.3 \%$ stable after the $1^{\text {st }}$ and $2^{\text {nd }}$ post-thaw cycles respectively (Table 4 ).

\section{3. Analysis of Buffalo Plasma Samples}

Representative chromatograms of blank plasma sample, plasma spiked with $10 \mu \mathrm{g} / \mathrm{mL}$ of ceftiofur, and samples collected at $10 \mathrm{~min}$ after the intramuscular and subcutaneous injections of ceftiofur hydrochloride in buffalo calves at $2.2 \mathrm{mg} / \mathrm{kg}$ body weight have been presented in Figure 2.

\section{Conclusion}

Ceftiofur, its metabolic derivatives and protein-bound residues were converted into desfuroylceftio- fur, derivatized and directly estimated as desfuroylceftiofur acetamide using an isocratic HPLC assay. Under the recommended chromatographic conditions, the linearity, accuracy, precision, sensitivity and recovery of proposed method remained within the acceptable limits. The suggested assay can be effectively used in pharmacokinetic studies for quantitative determination of ceftiofur hydrochloride in buffalo plasma.

\section{Acknowledgement}

The authors are thankful to Director, Quality Operations Laboratory, University of Veterinary and Animal Sciences (UVAS), Lahore for providing necessary facilities to carry out the research work. The authors also acknowledge $\mathrm{M} / \mathrm{S}$ International Pharma Labs, Lahore, Pakistan and M/S Nawan Laboratories (PVT) LTD., Karachi, Pakistan, for the provision of reference standard and injectable formulation of ceftiofur hydrochloride respectively.

\section{Conflict of Interest}

The authors declare no conflict of interests regarding the publication of this article.

\section{References}

1. R. E. Hornish, S. F. Kotarski, Curr. Top. Med. Chem. 2002, 2, 717. DOI:10.2174/1568026023393679

2. K. Palur, S. C. Archakam, N. Lingasani, R. Diviti, R. K. Kuma-
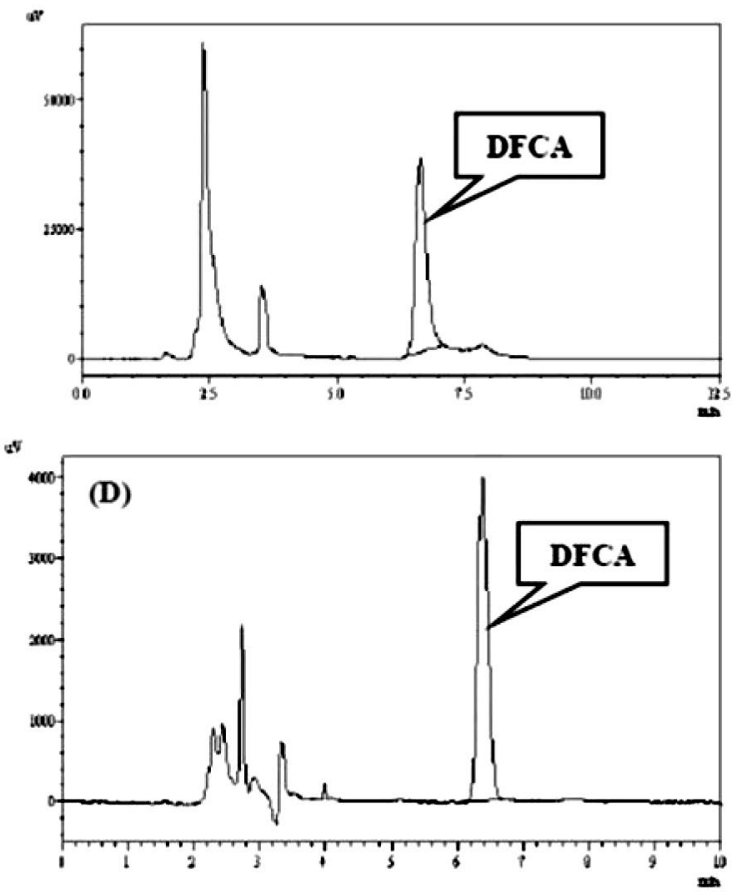

Figure 2. Representative chromatograms of blank buffalo plasma (A); buffalo plasma spiked with $10 \mu \mathrm{g} / \mathrm{mL}$ of ceftiofur hydrochloride (B); buffalo plasma sample collected at $10 \mathrm{~min}$ after intramuscular injection of ceftiofur hydrochloride (C); and buffalo plasma sample obtained at 10 min following the subcutaneous administration of ceftiofur hydrochloride (D). DFCA: Desfuroylceftiofur acetamide. 
rachari, S. Velusamy, J. Pharm. Res. 2013, 7, 246.

DOI:10.1016/j.jopr.2013.02.027

3. W. T. Collard, S. R. Cox, S. P. Lesman, G. S. Grover, J. F. Boucher, J. W. Hallberg, J. A. Robinson, S. A. Brown, J. Vet. Pharmacol. Ther. 2011, 34, 476.

DOI:10.1111/j.1365-2885.2011.01266.x

4. F. M. Kausche, E. J. Robb, Vet. Ther. 2003, 4, 83.

5. M. G. Papich, Saunders Handbook of Veterinary Drugs. Small and Large Animal, $4^{\text {th }}$ ed., Elsevier Saunders, St. Louis (MO), 2016, pp. 139-140.

DOI:10.1016/B978-0-323-24485-5.00147-9

6. S. A. Salmon, J. L. Watts, R. J. Yancey, J. Vet. Diagn. Invest. 1996, 8, 332. DOI:10.1177/104063879600800309

7. P. S. Jaglan, B. L. Cox, T. S. Arnold, J. Assoc. Off. Anal. Chem. 1990, 73, 26.

8. S. De Baere, F. Pille, S. Croubels, L. Ceelen, P. De Backer, Anal. Chim. Acta. 2004, 512, 75. DOI:10.1016/j.aca.2004.02.017

9. C. B. Navarre, L. Zhang, G. Sunkara, S. H. Duran, U. B. Kompella, J. Vet. Pharmacol. Ther. 1999, 22, 13. DOI:10.1046/j.1365-2885.1999.00186.x

10. G. A. Jacobson, S. Martinod, C. P. Cunningham, J. Pharm. Biomed. Anal. 2006, 40, 1249.

DOI:10.1016/j.jpba.2005.09.010

11. F. Altan, K. Uney, E. R. Ayse, G. Cetin, B. Dik, E. Yazar, M. Elmas, J. Vet. Med. Sci. 2017, 79, 1245.

DOI:10.1292/jvms.16-0641
12. ICH, Q2 (R1); Validation of analytical procedures: text and methodology, International Conference on Harmonization. Geneva, 2005, pp.11-12.

13. S. S. Panda, B. V. Kumar, G. Mohanta, Braz. J. Pharm. Sci. 2013, 49, 475. DOI:10.1590/S1984-82502013000300009

14. M. N. Irakli, V. F. Samanidou, C. G. Biliaderis, I. N. Papadoyannis, Food chem. 2012, 134, 1624.

DOI:10.1016/j.foodchem.2012.03.046

15. J. W. Wu, L. C. Lin, S. C. Hung, C. W. Chi, T. H. Tsai, J. Pharm. Biomed. Anal. 2007, 45, 635.

DOI:10.1016/j.jpba.2007.06.026

16. R. Gannu, S. Bandari, S. G. Sudke, Y. M. Rao, B. P. Shankar, Acta Chromatogr. 2007, 19, 149.

17. M. Aqil, A. Ali, A. Ahad, Y. Sultana, A. K. Najmi, N. Saha, 2007. Acta Chromatogr. 2007, 19, 130.

18. H. Nie, X. Feng, J. Peng, L. Liang, C. Lu, R. V. Tiwari, S. Tang, J. He, Am. J. Vet. Res. 2016, 77, 646.

DOI:10.2460/ajvr.77.6.646

19. M. G. Beconi-Barker, R. D. Roof, L. Millerioux, F. M. Kausche, T. H. Vidmar, E. B. Smith, J. K. Callahan, V. L. Hubbard, G. A. Smith, T. J. Gilbertson, J. Chromatogr. B Biomed. Sci. Appl. 1995, 673, 231.

DOI:10.1016/0378-4347(95)00258-1

20. K. Uney, F. Altan, M. Elmas, Antimicrob. Agents Chemother. 2011, 55, 854. DOI:10.1128/AAC.01126-10

\section{Povzetek}

Optimizirali in validirali smo izokratsko metodo na osnovi tekočinske kromatografije visoke ločljivosti (HPLC) za kvantitativno določanje ceftiofur hidroklorida v plazmi bivolov. Ceftiofur, njegove metabolne produkte in na beljakovine vezane ostanke smo derivatizirali $\mathrm{v}$ desfuroilceftiofur acetamid in injicirali $\mathrm{v}$ HPLC-sistem. Ločba je potekala $\mathrm{v}$ koloni $\mathrm{C} 18 \mathrm{z}$ uporabo mobilne faze sestavljene iz natrijevega dihidrogenfosfata $(0,025 \mathrm{M}, \mathrm{pH} 7)$ in acetonitrila $(34: 66$, v/v). Pretok je bil $1 \mathrm{~mL} / \mathrm{min}$, volumen injiciranja pa $45 \mu \mathrm{L}$. Detekcijo smo izvedli pri $310 \mathrm{~nm}$. Območje linearnosti je bilo 0,1-10 $\mu \mathrm{g} / \mathrm{mL}$, meja zaznave $0,03 \mu \mathrm{g} / \mathrm{mL}$, meja določitve pa $0,11 \mu \mathrm{g} / \mathrm{mL}$. Točnost, natančnost, izkoristek so ustrezali kriterijem. Metodo smo uporabili za določanje koncentracije ceftiofurja v vzorcih plazme bivoljih telet zdravljenih s ceftiofurjem.

Except when otherwise noted, articles in this journal are published under the terms and conditions of the Creative Commons Attribution 4.0 International License 